\title{
Specific properties of epithelial and stromal cells from the endometrium of cows
}

\author{
M. A. Fortier, L. A. Guilbault and F. Grasso \\ Ontogénie et Reproduction, Centre de Recherches en Endocrinologie Moléculaire, Centre \\ Hospitalier de l'Université Laval, Ste-Foy, Quebec, Canada G1V 4G2; and Station de Recherches, \\ Agriculture Canada, Lennoxville, Quebec, Canada J1M $1 Z 3$
}

\begin{abstract}
Summary. Epithelial and stromal cells were isolated from endometrium of cyclic heifers by enzymic dispersion. These cells exhibited specific morphological and functional properties. Epithelial cells appeared cuboidal or columnal and showed contact inhibition as they reached confluence. Stromal cells were fibroblast-like and enlarged at the time of confluence after which they overgrew in multiple layers. The presence of specific receptors for PGE-2 and $\beta$-adrenergic catecholamines (isoproterenol) was estimated by activation of adenylate cyclase. Stromal cells had more adenylate cyclase activity $(P<0.01)$ than did epithelial cells before (basal) and after stimulation with guanosine triphosphate (GTP) and PGE-2. However, epithelial cells were much more responsive to isoproterenol $(P<0.01)$. Treatment of cultured cells with indomethacin to block PG synthesis increased the sensitivity and maximal response to PGE-2 in stromal $(P<0.01)$ but not in epithelial $(P>0 \cdot 1)$ cells. The latter result suggested autologous desensitization of the PGE-2 response resulting from synthesis of PGs in cultured cells. Both cell types synthesized PGs in culture: PGF-2 $\alpha$ was synthesized in greater quantity in epithelial than in stromal cells $(P<0.05)$ while stromal cells synthesized more PGE-2 than did epithelial cells $(P<0.001)$. Endometrial cells separated in this way should prove useful for study of their specific role in the processes of implantation and maternal recognition of pregnancy.
\end{abstract}

Keywords: cattle; endometrium; cell culture; adenylate cyclase; prostaglandins

\section{Introduction}

There is growing evidence that interaction between the embryo and the maternal unit is a prerequisite to successful implantation and embryo development (Thatcher et al., 1985). Studies conducted in vivo constitute the most physiological condition to evaluate mutual influence between the conceptus and its host. However, a major drawback of the in-vivo situation is that local effects at the site of interaction may be masked by the anatomical complexity of the genital tract or by an influence of the whole maternal organism.

The contributions of the different tissue components of the uterus need to be characterized to provide a better understanding of the mechanisms involved in maternal recognition of pregnancy (Betteridge et al., 1980) and implantation. The different cell types of rat (McCormack \& Glasser, 1980) and human (Pavlik \& Katzenellenbogen, 1978; Varma et al., 1982) uteri when isolated and grown in culture have distinct properties with regard to growth response and presence of sex steroid receptors. Cell cultures have also permitted localization of uteroglobin synthesis in epithelial cells of rabbit endometrium (Rajkumar et al., 1983; Ricketts et al., 1983) and alkaline phosphatase activity in stromal cells of rat endometrium (Daniel \& Kennedy, 1987). Adenylate cyclase activity, which is believed to mediate some actions of prostaglandins (PGs) (Gardner et al., 1981), is greater 
and stimulated to a higher level by PGE-2 in stromal than in epithelial cells of rabbit endometrium (Fortier et al., 1987). In rats also, PGE-2 binding sites are localized in the stroma (Kennedy'et al., 1983).

Around implantation, prostaglandins such as PGE-2 are involved in several processes such as increase in vascular permeability (Kennedy, 1980, 1985) and changes in uterine blood flow (Burka, 1983) via their effect on cAMP (Kennedy, 1983). Likewise, PGF-2 $\alpha$ of uterine origin has been implicated in the process of luteolysis in cattle (Thatcher et al., 1984b, 1985) as well as in several other species (Horton \& Poyser, 1976).

The objective of the present study was to determine morphological and functional characteristics of primary cultures of epithelial and stromal cells isolated from bovine endometrium. Functional properties were evaluated by measurement of adenylate cyclase activity and its receptor-mediated stimulation and by determination of PGE-2 and PGF-2 $\alpha$ synthesis in vitro.

\section{Materials and Methods}

Isolation of endometrial cells. Epithelial and stromal cells from bovine endometrium were obtained by a modification of the ms 'hod described for rabbit endometrium (Fortier $e t$ al., 1987). Uteri from a total of 26 cyclic heifers were used in the present study. Genital tracts were collected at the slaughter house within $10 \mathrm{~min}$ of death of the animal, placed in sterile, incomplete $\left(\mathrm{Ca}^{2+}\right.$-and $\mathrm{Mg}^{2+}$-free) Hank's balanced salt solution (IHBSS) containing 100 units penicillin $/ \mathrm{ml}$ and $100 \mu \mathrm{g}$ streptomycin/ml and kept on ice until further processing at the laboratory. The physiological status of the animals was estimated by examination of ovarian morphology (Ireland et al., 1979).

The recovery of endometrial cells and their viability after dispersion were optimal during early to mid-luteal phase (Day 2 to 12) of the oestrous cycle. Accordingly, only genital tracts from animals in this period were used in the present experiments. Typically uterine horns from 1 or 2 heifers were used for each cell preparation.

The following procedures were performed aseptically under a laminar flow hood. The broad ligament was removed from uterine horns and the myometrium was dissected with scissors in longitudinal bands leaving the endometrium free of vascular and smooth muscle tissue. The endometrium was inverted to expose luminal epithelium and sections weighing $5-8 \mathrm{~g}$ were placed individually in $50 \mathrm{ml}$ conical tubes containing $0.300 \%$ trypsin (Sigma, St Louis, MO, U.S.A.; Type III-S) in $20 \mathrm{ml}$ IHBSS. The tissue was digested for $3 \mathrm{~h}$ at $22^{\circ} \mathrm{C}$ with gentle shaking ( $40 \mathrm{strokes} / \mathrm{min}$ ). Each section of uterine horn was rinsed with $15 \mathrm{ml}$ IHBSS and scraped with forceps to remove remaining luminal epithelial cells. The section of tissue was placed in a new conical tube containing trypsin $(0.02 \%)$, collagenase (Sigma; Type II, $0.02 \%$ ) and DNase-I (Sigma, $0.015 \%$ ) in $15 \mathrm{ml} \mathrm{IHBSS}$ and incubated at $37^{\circ} \mathrm{C}$ for $1 \mathrm{~h}$ with vigorous shaking (150 strokes/min).

The cell suspension obtained from the first digestion was combined with that obtained after the first rinse. The action of trypsin was inhibited by addition of $30 \mathrm{ml} \mathrm{10 \%} \mathrm{fetal} \mathrm{bovine} \mathrm{serum} \mathrm{(FBS;} \mathrm{Flow} \mathrm{Laboratories,} \mathrm{McLean,} \mathrm{VA,}$ U.S.A.) and epithelial cells were recovered by centrifugation at $500 \mathrm{~g}$ for $15 \mathrm{~min}$. The cell pellets were resuspended in $20 \mathrm{ml}$ IHBSS and deposited on $20 \mathrm{ml}$ Ficoll hypaque (Pharmacia, Uppsala, Sweden) gradient to eliminate contaminating erythrocytes. The gradients were centrifuged at $2000 \mathrm{~g}$ for $30 \mathrm{~min}$, epithelial cells were recovered at the interface

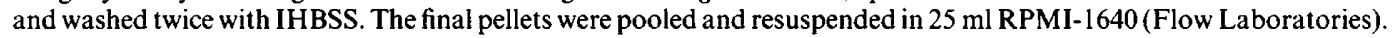
A sample of the suspension was diluted 500 -fold and the cells were counted in three $20 \mu \mathrm{l}$ samples. Epithelial cells appeared in clumps or sheets of up to 100 cells and were all included in the total count. Cells were diluted to $0.5 \times 10^{6}$ cells per ml in RPMI- 1640 containing $50 \mu \mathrm{g}$ penicillin/ml, $50 \mu \mathrm{g}$ streptomycin $/ \mathrm{ml}$ and supplemented with $10 \%$ heat-inactivated FBS. For culture, $10 \mathrm{ml}$ cell suspension were placed in $25 \mathrm{~cm}^{2}$ culture flasks (Falcon, Oxnard, CA, U.S.A.).

Stromal cells were recovered from the second digestion and processed like epithelial cells except for Ficoll gradient centrifugation which was omitted. Stromal cells which are fibroblast-like attached quickly to the culture dishes and could be separated from erythrocytes and remaining epithelial cells by pre-plating for $18 \mathrm{~h}$. Cells were fed on the 4 th and 7 th days of culture.

Recovery of cells, protein and DNA determinations. Cells were harvested at the stage of confluence after 6-7 days in culture unless otherwise specified. The culture medium was discarded, $10 \mathrm{ml}$ IHBSS were added to the culture flask and cells were scraped off with a plastic policeman. The flask was rinsed with $10 \mathrm{ml}$ IHBSS and cells were recovered by centrifugation at $500 \mathrm{~g}$ for $15 \mathrm{~min}$. Growth was estimated by levels of protein, measured by the folin-phenol reagent (Lowry et al., 1951) and of DNA, determined by diphenylamine analysis (Burton, 1956) in the cell pellet resuspended in $0.4 \mathrm{~N}$-perchloric acid.

Determination of adenylate cyclase activity in cultured cells and fresh tissue. Adenylate cyclase (EC 4.6.1.1) activity was defined as the enzymic conversion of $\alpha-\left[{ }^{32} \mathrm{P}\right] \mathrm{ATP}$ to $\left[{ }^{32} \mathrm{P}\right] \mathrm{cAMP}$ in $5 \mathrm{~min}$ in broken cell preparation from cultured cells or fresh tissue. The method was as used previously for rat and rabbit cells in culture (Fortier et al., 1983, 1987) and described in detail elsewhere (Krall \& Korenman, 1979). The activity was measured in the basal state and after stimulation with guanosine triphosphate (GTP, $75 \mu \mathrm{M}$ ). Receptor mediated stimulation was measured in presence of GTP $(75 \mu \mathrm{M})$ at optimal concentrations of agonists: PGE-1, PGE-2 and PGF-2 $\alpha$ at $100 \mu \mathrm{M}$ and isoproterenol, a 
$\beta$-adrenergic stimuiant, at $10 \mu \mathrm{m}$. Adenylate cyclase activity was measured in confluent epithelial and stromal cells and in fresh endometrium prepared as described below.

Cells, recovered as described for the protein assay, were resuspended in cyclase homogenization buffer (Buffer $\mathrm{CH}, \mathrm{pH} 7.6)$ composed of $0.05 \mathrm{M}-\mathrm{Na}^{+}-N$-2-hydroxyethylpiperazine- $N^{\prime}$-2-ethane sulphonic acid (Hepes), $0.001 \mathrm{M}-$ ethyleneglycol-bis-(amino-ethylether)- $N, N^{\prime}$-tetraacetic acid (EGTA) and $10 \%$ dimethyl sulphoxide (DMSO), at $4^{\circ} \mathrm{C}$. Cells, broken osmotically, were washed twice by centrifugation at $30000 \mathrm{~g}$ for $20 \mathrm{~min}$ and the final pellet was resuspended in Buffer $\mathrm{CH}$ at an equivalent of $1.0 \mathrm{mg}$ protein $/ \mathrm{ml}$ and the preparation was used fresh.

Fresh endometrial tissue was obtained by cutting a section of uterine horn after removal of myometrium as described for cell preparation. The tissue was weighed and diluted in 10 volumes Buffer $\mathrm{CH}$ at $4^{\circ} \mathrm{C}$ and homogenized with a tissue disintegrator (Brinkman PT-10) adjusted to 5 for $20 \mathrm{sec}$. The homogenate was filtered through glass wool and centrifuged at $30000 \mathrm{~g}$ for $20 \mathrm{~min}$ at $4^{\circ} \mathrm{C}$. The pellet was washed twice, resuspended in Buffer $\mathrm{CH}$ to obtain a protein concentration between 1.0 and $1.5 \mathrm{mg} / \mathrm{ml}$ and used fresh.

Determination of prostaglandins. Cells obtained from 5 cyclic cows were grown as described above until early confluence was observed on Days 6-7 for stromal cells and 10-12 for epithelial cells. Then the culture medium was discarded and the culture flasks were rinsed with $10 \mathrm{ml}$ IHBSS. The medium was replaced with $10 \mathrm{ml} \mathrm{RPMI}-1640$ without FBS but containing arachidonic acid $(200 \mu \mathrm{g} / \mathrm{ml})$, or indomethacin $(10 \mathrm{nM})$, at a final concentration of $0.01 \%$ ethanol. Ethanol at $0.01 \%$ alone was added in the control group. Epithelial and stromal cells in the presence of arachidonic acid, indomethacin or neither were cultured in duplicate or triplicate for each cow. After $24 \mathrm{~h}$ the culture medium was recovered and frozen until assayed for PGE- 2 and PGF- $2 \alpha$ content. Cells from corresponding flasks were scraped and kept for determination of protein as described earlier. PGE-2 and PGF-2 $\alpha$ were evaluated in acidified aliquants $(1 \mathrm{ml})$ of culture medium extracted twice with 2.5 volumes of ethyl acetate. The organic phase was evaporated to dryness in a vacuum chamber initially flushed with nitrogen and rediluted in phosphate buffer ( $100 \mathrm{~mm}$ $\mathrm{Na}_{2} \mathrm{HPO}_{4}, \mathrm{NaH}_{2} \mathrm{PO}_{4}, \mathrm{pH} 7 \cdot 4$ ). Radioimmunoassays of PGF-2 $\alpha$ and PGE-2 were done without any further purification as described by Evans et al. (1982) and Olson et al. (1984) using the same fully characterized antisera. Recoveries of tritiated PGF- $2 \alpha$ and PGE- 2 were $94 \%$ and $92 \%$ respectively. Intra- and interassay coefficients of variation were $10 \cdot 0$ and $10 \cdot 3 \%$ for PGF- $2 \alpha$ and 6.0 and $10.4 \%$ for PGE-2.

Statistical analysis. Data were treated by analysis of variance (ANOVA).

\section{Results}

The anatomical distribution of the different tissue components of the bovine uterus allows the separation of myometrium and endometrium by dissection with scissors. A cross-section of endometrium after removal of myometrium and inversion is illustrated in Fig. 1(a). Figure 1(b) represents a cross-section from the same tissue after the first digestion with trypsin. Only epithelial cells from the lumen have been removed by the process. At the time of plating the viability of epithelial cells estimated by trypan blue dye exclusion was greater than $95 \%$. These cells were released in clumps of different sizes (Fig. Ic) and attached progressively over a period of up to $72 \mathrm{~h}$ after plating. Epithelial cells exhibited cuboidal or columnar morphologies and showed contact inhibition at confluence (Fig. 1d). Stromal cells were obtained after digestion with trypsin-collagenase-DNase and consisted of a mixture of fibroblasts, erythrocytes and luminal and glanular epithelial cells. Live stromal cells attached to culture dishes within $18 \mathrm{~h}$ and other contaminating cells such as erythrocytes, luminal, glandular and dead cells were eliminated by replacement of the culture medium $18 \mathrm{~h}$ after plating. This process yielded a homogeneous population of cells with fibroblastic shapes (Fig. 1e) until the stage of confluence when they enlarged and formed concentric colonies (Fig. 1f).

Measurement of protein and DNA contents permitted evaluation of the growth patterns of endometrial cells in cuture. Protein and DNA followed a parallel increase with time in culture (Figs $2 \mathrm{a}, \mathrm{b})$ and growth patterns were different in the two cell types. The initial growth of epithelial cells was hindered by the delay in their attachment to the culture dish but there was a shorter doubling time between Days 5 and 7. Epithelial cells reached confluence between Days 8 and 12. Stromal cells grew rapidly at first but then slowed down on Days 5-6 as the cultures approached confluence. Adenylate cyclase activity was detected in fresh endometrial tissue as well as in both types of endometrial cells. In both fresh tissue (Fig. 3) and endometrial cells (Fig. 4), basal adenylate cyclase activity was stimulated with GTP. Compared to GTP alone, addition of PGE-1, PGE-2 and isoproterenol increased adenylate cyclase activity in fresh tissue by 50,35 and $29 \%$ respectively, whereas addition of PGF- $2 \alpha$ had no effect. In cultured cells, basal and stimulated adenylate cyclase activities were always lower $(P<0.01)$ in epithelial than in stromal (Fig. 4) cells but both cell types 


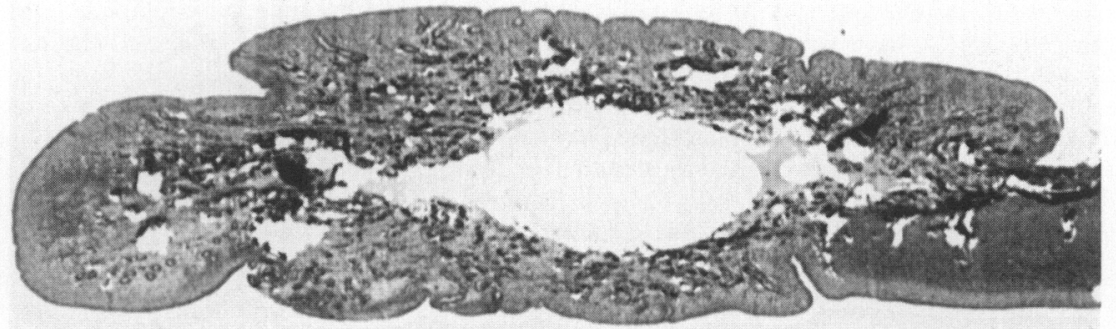

a

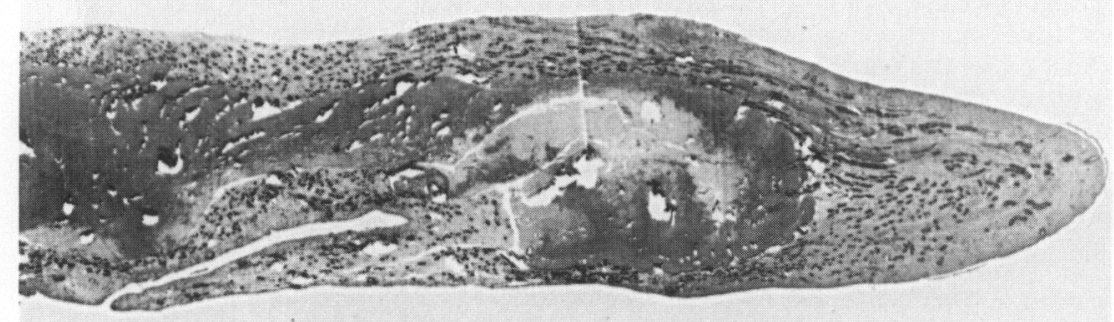

b
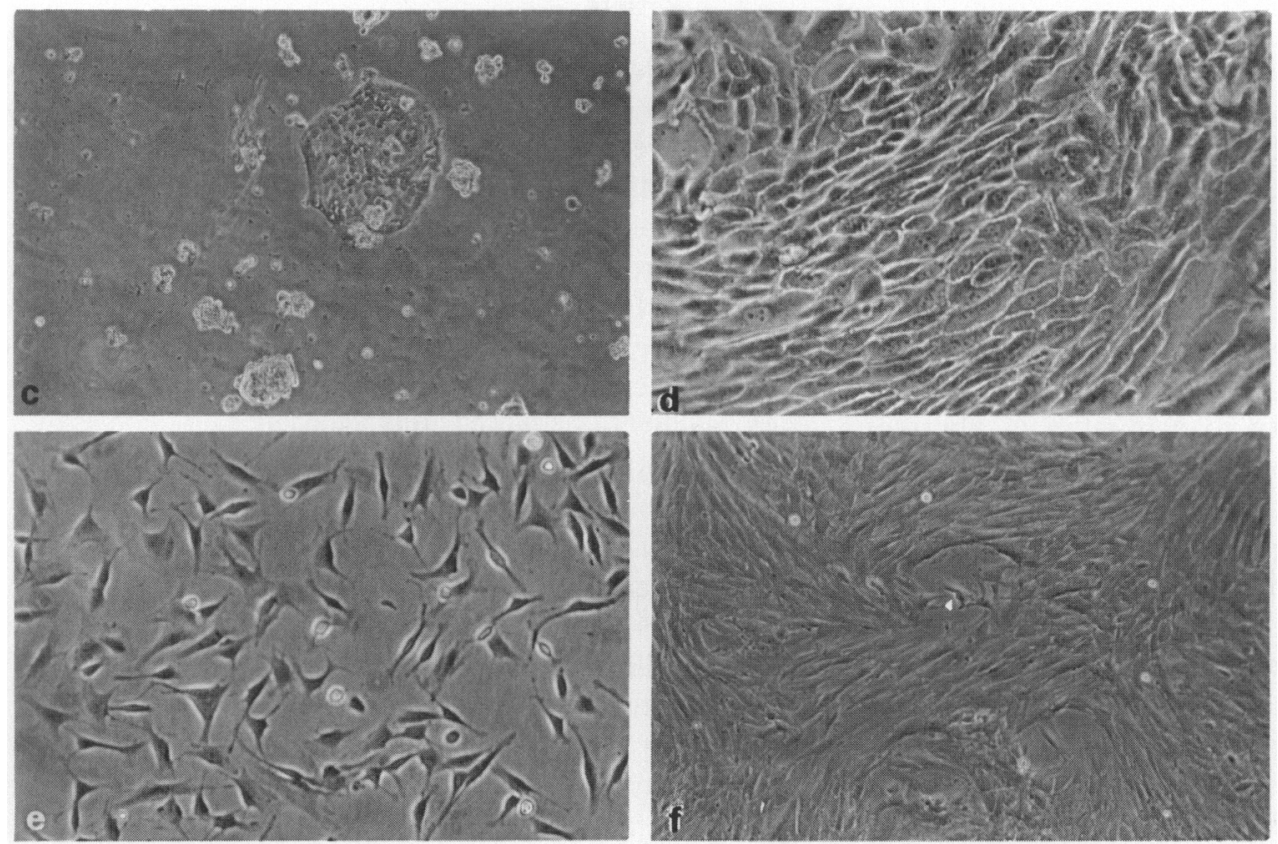

Fig. 1. Illustration of different steps in the preparation of cultured cells from bovine endometrium: (a) cross-section of inverted bovine endometrium after dissection of myometrium; (b) cross-section of the same tissue after removal of epithelial cells by the first digestion; (c) epithelial cells $36 \mathrm{~h}$ after plating; (d) epithelial cells at the stage of early confluence on Day 7 ; (e) stromal cells $36 \mathrm{~h}$ after plating and $18 \mathrm{~h}$ after removal of contaminating cells by pre-plating; (f) stromal cells at the stage of early confluence on Day 6. a, b $\times 2$; c, $f \times 100$; d, e $\times 200$. 


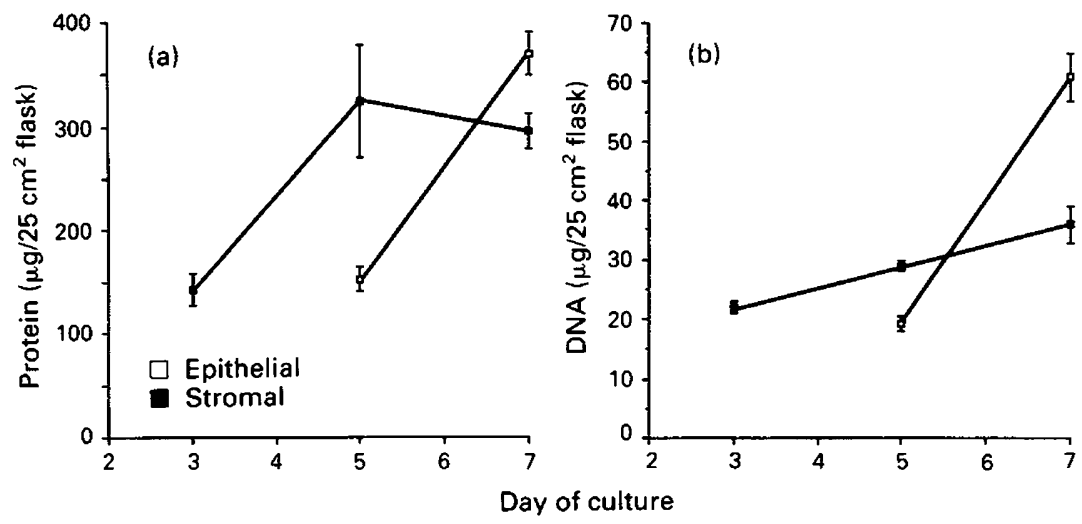

Fig. 2. Growth patterns of epithelial and stromal cells in culture. Each point represents the mean \pm s.e.m. of 4 cell preparations run in triplicate.

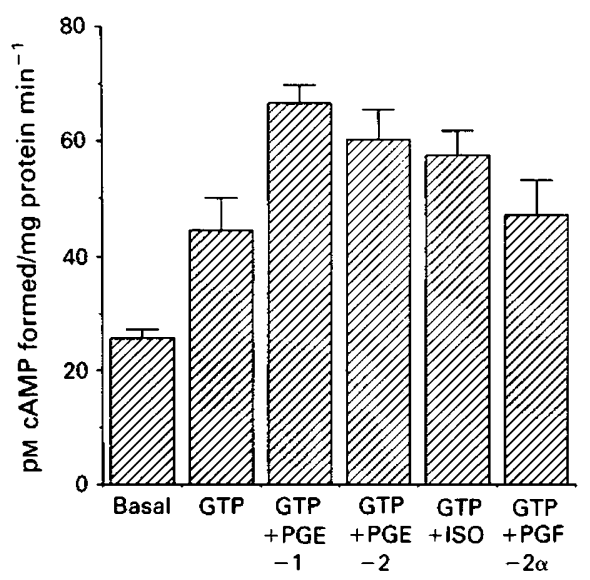

Fig. 3. Adenylate cyclase activity in fresh bovine endometrium. Activity was measured with no addition (basal) and after stimulation with GTP $(75 \mu \mathrm{M})$ or with GTP + PGE-1, PGE-2 or PGF- $2 \alpha(100 \mu \mathrm{M})$ or GTP + isoproterenol (ISO) $(10 \mu \mathrm{M})$. Results are the mean \pm s.e.m. of 3 replicates from one representative experiment.

responded to isoproterenol and PGE-2. When stimulation was expressed as net agonist response (GTP + isoproterenol or GTP + PGE-2, less GTP alone), net isoproterenol response was greater in epithelial than in stromal cells $(P<0.001)$ (Fig. 4). Nevertheless, PGE-2 response tended to be higher in stromal $(P=0.06)$ than in epithelial cells.

The effect of treatment of cultured cells with indomethacin, an inhibitor of PG synthesis, on the stimulation of adenylate cyclase with PGE-2 is illustrated in Fig. 5. The analysis of dose-response curves with a test of homogeneity of regression indicated that indomethacin influenced significantly the response to PGE-2 in stromal $(P<0 \cdot 01$, Fig. 5a) but not in epithelial $(P>0 \cdot 1$, Fig. 5b) cells. Maximal response of the stromal cells was increased $2 \cdot 4$-fold $(P<0.001)$ and sensitivity (estimated by threshold) increased 100 -fold from 10 to $0.1 \mathrm{~nm}$.

Production of prostaglandin over a 24 -h period was measured in confluent cultures of epithelial and stromal cells. Table 1 summarizes the results. Compared to control, addition of arachidonic acid increased $(P<0.001)$ whereas addition of indomethacin inhibited $(P<0.001)$ production of 


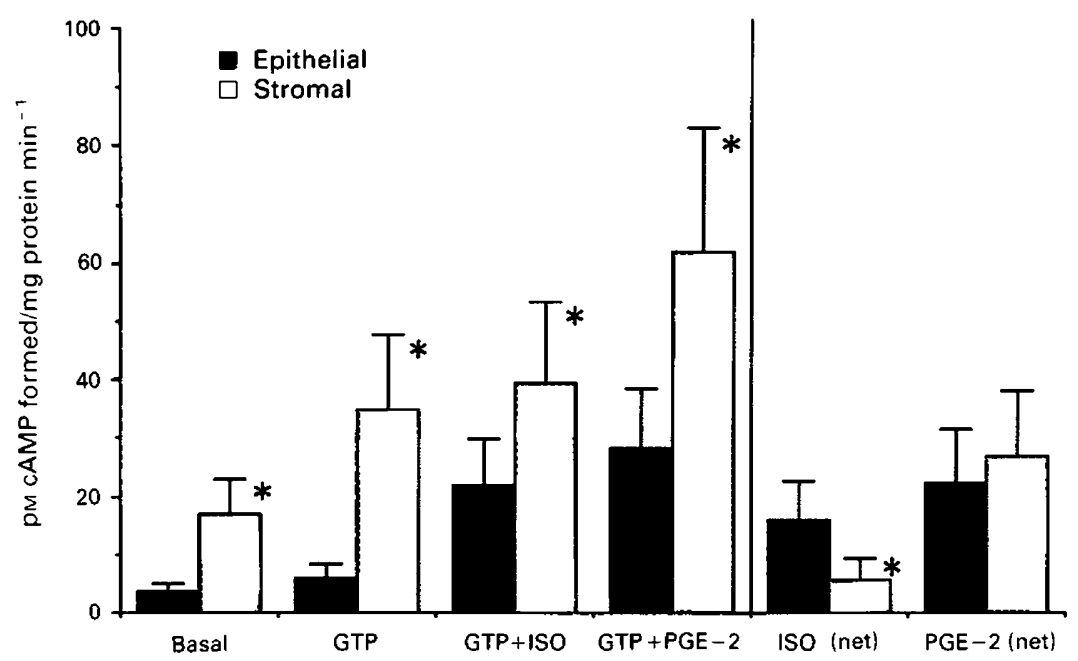

Fig. 4. Adenylate cyclase activity in cultured epithelial and stromal cells harvested on Day 7. Activity was compared with no addition (basal) and after stimulation with GTP (75 $\mu \mathrm{M})$ alone or in the presence of isoproterenol (ISO) $(10 \mu \mathrm{M})$ or PGE-2 $(10 \mu \mathrm{M})$. The right panel illustrates the net stimulation, defined as activity measured in the presence of GTP + ISO or GTP + PGE-2 less activity with GTP alone. Results are the mean \pm s.e.m. of 6 cell preparations run in triplicate. ${ }^{*} P<0.01$ compared with value in epithelial cells.

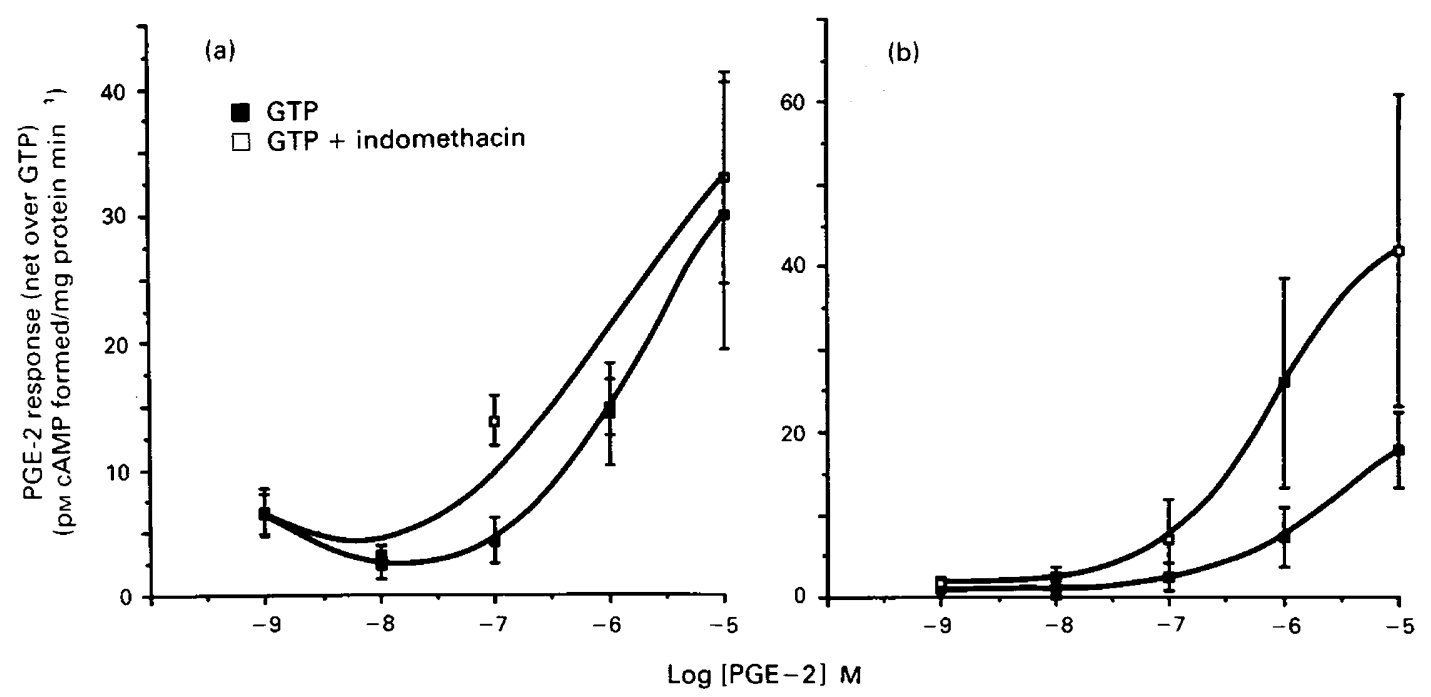

Fig. 5. Influence of treatment of cultured (a) epithelial and (b) stromal cells with indomethacin $(10 \mu \mathrm{M})$ on adenylate cyclase activity. Results are the mean \pm s.e.m. of 2 (a) or 3 (b) cell preparations run in triplicate. 
Table 1. Production (ng/mg protein) of PGE-2 and PGF-2 $\alpha$ by cultured epithelial and stromal cells from the endometrium of cows

\begin{tabular}{|c|c|c|c|c|c|c|}
\hline \multirow[b]{2}{*}{ Cells } & \multicolumn{3}{|c|}{ PGE-2 } & \multicolumn{3}{|c|}{ PGF-2 $\alpha$} \\
\hline & Control & $\begin{array}{l}\text { Arachidonic } \\
\text { acid }\end{array}$ & Indomethacin & Control & $\begin{array}{l}\text { Arachidonic } \\
\text { acid }\end{array}$ & Indomethacin \\
\hline Epithelial & $\begin{array}{c}10 \cdot 3^{\mathrm{a}} \\
\pm 1 \cdot 4^{* *}\end{array}$ & $\begin{array}{c}330 \cdot 3^{b} \\
\pm 47 \cdot 1^{* *}\end{array}$ & $\begin{array}{c}3 \cdot 3^{\mathrm{c}} \\
\pm 0 \cdot 7^{* *}\end{array}$ & $\begin{array}{r}131 \cdot 4^{x} \\
\pm 32 \cdot 2^{*}\end{array}$ & $\begin{array}{r}766 \cdot 3^{y} \\
\pm 291 \cdot 6^{*}\end{array}$ & $\begin{array}{r}39 \cdot 1^{2} \\
\pm 7 \cdot 9^{*}\end{array}$ \\
\hline Stromal & $\begin{aligned} & 183 \cdot 3^{a} \\
\pm & 41 \cdot 8\end{aligned}$ & $\begin{array}{l}1726.0^{\mathrm{b}} \\
\pm 511 \cdot 2\end{array}$ & $\begin{array}{r}49 \cdot 3^{\mathrm{c}} \\
\pm 12 \cdot 5\end{array}$ & $\begin{array}{r}65.5^{x} \\
\pm 9.9\end{array}$ & $\begin{array}{r}486 \cdot 0^{y} \\
\pm 132 \cdot 7\end{array}$ & $\begin{aligned} & 14 \cdot 4^{z} \\
\pm & 4 \cdot 0\end{aligned}$ \\
\hline
\end{tabular}

Values are mean \pm s.e.m. of 5 cell preparations run in triplicate.

${ }^{*} P<0.05,{ }^{* *} P<0.001$ compared with values for stromal cells.

For cell type and $\mathrm{PG}$ product, values with different superscript letters are significantly different, $P<0.001$.

PGE-2 and PGF-2 $\alpha$ by epithelial and stromal cells. Production of PGF-2 $\alpha$ was higher in epithelial than in stromal cells $(P<0.05)$ while that of PGE-2 was higher in stromal cells $(P<0.001)$ for all 3 conditions.

\section{Discussion}

Separation and culture of epithelial and stromal cells from endometrium have been reported for several species including human (Liu \& Tseng, 1979), rat (McCormack \& Glasser, 1980) and rabbit (Gerschenson et al., 1981; Fortier et al., 1987) but not for cattle. There seems to be little species-tospecies variation in the morphology of these cells in culture. In our study, we have used a slight modification of the method previously published for rabbit endometrium (Fortier et al., 1987). Centrifugation of the epithelial cell fraction on Ficoll hypaque eliminated erythrocytes and eventually fibroblasts of densities greater than that of epithelial cells. Similarly, pre-plating of the stromal cell fraction for $18 \mathrm{~h}$ eliminated unattached erythrocytes and epithelial cells. These processes yielded homogeneous populations of cells with purities greater than $85 \%$ as assessed subjectively under a phase-contrast microscope. No in-depth characterization of the cells using histochemistry, electron microscopy or antibody labelling was performed on these cells, since similar methods of preparation reported a good correlation between gross morphology and ultrastructure for the individual cell types (Varma et al., 1982; Ricketts et al., 1983; Boulet \& Fortier, 1987). The differences observed between the two cell types with regard to growth patterns, presence of $\beta$-adrenergic and PGE-2 response and synthesis of PGE- 2 and PGF- $2 \alpha$ confirmed, however, that these populations of cells were distinct and properly separated.

Adenylate cyclase activity was detected in fresh endometrium obtained by scraping, a preparation which represented a mixture of epithelial and, in greater proportions, stromal tissue. In cultured cells, the activity of the enzyme in its basal and stimulated state was much lower in epithelial than in stromal cells, as found in the rabbit (Fortier et al., 1987). However, the net response to PGE-2 and isoproterenol of epithelial cells reached levels similar to or higher than those of stromal cells. This result could not be attributed to contamination of epithelial cells with stromal cells. Indeed, the relative importance of the isoproterenol and PGE-2 response was completely different in the two cell types and may actually be a way to differentiate them. The stimulation of adenylate cyclase by isoproterenol in our preparation of epithelial cells was not unexpected: $\beta$-adrenergic receptors have been detected in rat oviduct and uterus by photoaffinity labelling (Tolszczuk et al., 1985) and, in the rabbit, isoproterenol stimulated adenylate cyclase in epithelial cells isolated from the oviduct and uterus (Fortier \& Boulanger, 1986). 
Specific mechanisms that may be regulated by $\beta$-adrenergic stimulation in epithelium include secretion activity (Baum et al., 1981), motility of cell surface cilia (Verdugo \& Villalon, 1983) and synthesis of PGs (Chaud et al., 1986). The $\beta$-adrenergic control of PG synthesis would be in agreement with the model proposed by McCracken et al. (1984) in which an increase in adenylate cyclase activity would be responsible for regulation of PGF- $2 \alpha$ synthesis in the uterus. In the present study, when cells were treated with indomethacin, subsequent stimulation of adenylate cyclase with PGE2 was not affected significantly in epithelial cells, but it increased both maximal response and sensitivity in stromal cells. The latter result suggested synthesis of PGE-2 and autologous desensitization in stromal cells. This was confirmed by measurement of PGs released in media by cultured cells. Stromal cells synthesized and released PGE-2 in greater quantity than did epithelial cells. In contrast, epithelial cells synthesized and released more PGF-2 $\alpha$ than did stromal cells. PG synthesis therefore appears to be another way to differentiate the two cell types. The in-vitro synthesis of PGs has been measured in explants from endometrium of cyclic or early pregnant cows (Lewis et al., 1982; Thatcher et al., 1984a) and of post-partum cows (Guilbault et al., 1984) but the contribution of individual cell types could not be determined. In endometrial explants, the stimulation of PG synthesis by arachidonic acid was not observed consistently (Thatcher et al., 1984b; Lewis, 1986). In the present experiment, production of PGF- $2 \alpha$ as well as that of PGE-2 was stimulated by exogenous arachidonic acid and inhibited by addition of indomethacin. Therefore, epithelial and stromal cells of the bovine endometrium in culture appear to have a limited pool of endogenous arachidonic acid.

The observation that the production of PGF- $2 \alpha$ predominates in culture media from epithelial cells may be related to data obtained from ewes (Lacroix \& Kann, 1983) and cows (Gross et al., 1987 ) indicating that concentrations in the perifusion medium from the luminal side of the endometrium were higher than those in medium from the myometrial side. Indeed, the luminal side of the endometrium is lined by epithelial cells whereas the myometrial side is primarily composed of stromal cells. The present study extends previous data by showing that stromal cells may account for a large proportion of PGE-2 synthesis.

The physiological function of epithelial and stromal cells is still uncertain. However, the tissues may act alone or in concert and through their specific PG synthetic capabilities, on vascular permeability (Kennedy, 1980, 1985) and blood flow (Ford et al., 1979) which are altered before implantation or at the time of maternal recognition of pregnancy. Likewise, the involvement of epithelial and stromal cells of the bovine endometrium with the luteolytic and/or luteotrophicantiluteolytic (Gimenez \& Henricks, 1983) processes (see review by Thatcher et al., 1986) during maternal recognition of pregnancy needs to be further characterized. Endometrial slices are able to direct blastocyst metabolism of arachidonic acid from synthesis of PGF-2 $\alpha$ toward synthesis of PGE-2 (Lewis, 1986). Specific properties of epithelial and stromal cells may be implicated and relate to embryo survival.

This work was supported by grants from Natural Sciences and Engineering Research Council of Canada \#U0389 and by Le Conseil de Recherches en Sciences Agricoles du Québec. LM-85-B2007. We thank Dr D. T. Armstrong (MRC Group in Reproductive Biology, University of Western Ontario) for provision of antibodies for determination of PGs; Mrs N. Breton for technical assistance; and Mr R. Dubreuil and Mr R. Montmigny for providing animal tissues under aseptic conditions. Agriculture Canada Research Station contribution no. 201.

\section{References}

Baum, B.J., Freibert, J.M., Ito, I., Roth, E.S. \& Filburn, C.R. (1981) $\beta$-adrenergic regulation of protein phosphorylation and its relationship to exocrine secretion in dispersed rat parotid gland acinar cells. J. biol. Chem. 256, 9731-9736.
Betteridge, K.J., Eaglesome, M.D., Randall, G.C.B. \& Mitchell, D. (1980) Collection, description and transfer of embryos from cattle 10-16 days after oestrus. J. Reprod. Fert. 59, 205-216.

Boulet, A.P. \& Fortier, M.A. (1987) Preparation and 
characterization of rabbit myometrial cells in primary culture: influence of estradiol and progesterone treatment. In vitro 23, 93-99.

Burka, J.F. (1983) Arachidonic acid metabolites and smooth muscle. In Biochemistry of Smooth Muscle, vol. III, pp. 141-168. Ed. N. L. Stephens. CRC Press, Boca Raton.

Burton, K. (1956) A study of the conditions and mechanisms of the diphenylamine reaction for the colorimetric estimation of DNA. Biochem. J. 62, 315-322.

Chaud, M.A., Franchi, A. M., Gonzalez, E.T., Gimeno, M.F. \& Gimeno, A.L. (1986) Norepinephrine alters $\mathrm{PGE}_{2} / \mathrm{PGE}_{1}$ output ratio in isolated uterus from ovariectomized rats. Prostaglandins Leukotrienes Med. 22, 201-210.

Daniel, S.A.J. \& Kennedy, T.G. (1987) Prostaglandin $E_{2}$ enhances uterine stromal cell alkaline phosphatase activity in vitro. Prostaglandins 33, 241-252.

Evans, C.A., Kennedy, T.G. \& Challis, J.R.G. (1982) Gestational changes in prostanoid concentrations in intrauterine tissues and fetal fluids from pregnant sheep and the relation to prostanoid output in vitro. Biol. Reprod. 27, 1-11.

Ford, S.P., Chenault, J.R. \& Eckternkamp, S.E. (1979) Uterine blood flow of cows during the oestrous cycle and early pregnancy: effect of the conceptus on the uterine blood supply. J. Reprod. Fert. 56, 53-62.

Fortier, M.A. \& Boulanger, M. (1986) Detection and regulation of hormone sensitive adenylate cyclase in epithelial cells from rabbit uterus and oviduct. Biol. Reprod. 34, 193. Abstr. 287.

Fortier, M., Chase, D., Korenman, S.G. \& Krall, J.F. (1983) $\quad \beta$-adrenergic catecholamine-dependent properties of rat myometrium primary cultures. $\mathrm{Am}$. J. Physiol. 245 (Cell Physiol. 14), C84-C90.

Fortier, M.A., Boulanger, M., Boulet, A.P. \& Lambert, R.D. (1987) Cell specific localization of prostaglandin $\mathrm{E}_{2}$ sensitive adenylate cyclase in rabbit endometrium. Biol. Reprod. 36, 1025-1033.

Gardner, D.G., Brown, E.M., Attie, M.F. \& Aurback, G.D. (1981) Effects of prostaglandins on adenosine $3^{\prime}, 5^{\prime}$-monophosphate content and adenylate cyclase activity in dispersed bovine parathyroid cells. Endocrinology 109, 1545-1551.

Gerschenson, L.E., Depaoli, J.R. \& Murai, J.T. (1981) Inhibition of estrogen-induced proliferation of cultured rabbit uterine epithelial cells by a cell densitydependent factor produced by the same cells. $J$. Steroid Biochem. 14, 959-969.

Gimenez, T. \& Henricks, D.M. (1983) Prolongation of the luteal phase by prostaglandin $E_{2}$ during the estrous cycle in the cow. A preliminary report. Theriogenology 19, 693-700.

Guilbault, L.A., Thatcher, W.W., Drost, M. \& Hopkins, S.M. (1984) Source of F series prostaglandins during the early postpartum period in cattle. Biol. Reprod. 31, 879-887.

Gross, T.S., Thatcher, W.W., Lacroix, M.C. \& Hansen, P.J. (1987) In vitro prostaglandin secretion from luminal and myometrial sides of cyclic and pregnant bovine endometrium at day 17 post-estrus. J. Anim. Sci. 65, (Suppl. 1), 383, abstr.
Horton, E.W. \& Poyser, N.L. (1976) Uterine luteolytic hormone: A physiological role for prostaglandin $\mathrm{F}_{2}$ a. Physiol. Rev. 56, 595-651.

Ireland, J.J., Coulson, P.B. \& Murphee, R.L. (1979) Follicular development during four stages of the estrous cycle of beef cattle. J. Anim. Sci. 49, 1261-1269.

Kennedy, T.G. (1980) Prostaglandins and the endometrial vascular permeability changes preceding blastocyst implantation and decidualization. Prog. Reprod. Biol. 7, 234-243.

Kennedy, T.G. (1983) Prostaglandin $E_{2}$, adenosine $3^{\prime}: 5^{\prime}$-cyclic monophosphate and changes in endometrial vascular permeability in rat uteri sensitized for the decidual cell reaction. Biol. Reprod. 29, $1069-1076$.

Kennedy, T.G. (1985) Evidence for the involvement of prostaglandins throughout the decidual cell reaction in the rat. Biol. Reprod. 33, 140-146.

Kennedy, T.G., Martel, D. \& Psychoyos, A. (1983) Endometrial prostaglandin $E_{2}$ binding during the estrous cycle and its hormonal control in ovariectomized rats. Biol. Reprod. 29, 565-571.

Krall, J.F. \& Korenman, S.G. (1979) Regulation of uterine smooth muscle cell beta-adrenergic catecholaminesensitive adenylate cyclase by $\mathrm{Mg}^{++}$and guanyl nucleotide. Biochem. Pharmacol. 28, 2771-2775.

Lacroix, M.C. \& Kann, G. (1983) Discriminating analysis of 'in vitro' prostaglandin release by myometrial and luminal sides of the ewe endometrium. Prostaglandins 25, 853-869.

Lewis, G.S. (1986) Effects of superovulation, arachidonic acid or endometrium on release of prostaglandins and synthesis of proteins by bovine trophoblast. Prostaglandins 32, 275-290.

Lewis, C.S., Thatcher, W.W., Bazer, F.W. \& Curl, J.S. (1982) Metabolism of arachidonic acid in vitro by bovine blastocysts and endometrium. Biol. Reprod. 27, 431-439.

Liu, H.C. \& Tseng, L. (1979) Estradiol metabolism in isolated human endometrial epithelial glands and stromal cells. Endocrinology 104, 1674-1681.

Lowry, O.H., Rosebrough, N.J., Farr, A.L. \& Randall, R.J. (1951) Protein measurement with the folin phenol reagent. J. biol. Chem. 193, 265-275.

McCormack, S.A. \& Glasser S.R. (1980) Differential response of individual uterine cell types from immature rats treated with estradiol. Endocrinology 106, 1634-1649.

MeCracken, J.A., Schramm, W. \& Okulicz, W.C. (1984) Hormone receptor control of pulsatile secretion of $\mathrm{PGF}_{2} \alpha$ from the ovine uterus during luteolysis and its abrogation in early pregnancy. Anim. Reprod. Sci. 7, $31-55$.

Olson, D.M., Lye, S.J., Skinner, K. \& Challis, J.R.G. (1984) Early changes in prostaglandins concentrations in ovine maternal and fetal plasma amniotic fluid and from dispersed cells of intrauterine tissues before the onset of ACTH-induced pre-term labour. J. Reprod. Fert. 71, 45-55.

Pavlik, E.J. \& Katzenellenbogen, B.S. (1978) Human endometrial cells in primary tissue culture: estrogen interactions and modulation of cell proliferation. $J$. clin. Endocr. Metab. 47, 333-344. 
Rajkumar, K., Bigbsby, R., Liebeiman, R. \& Gershenson, L. E. (1983) Uteroglobin production by cultured rabbit uterine epithelial cells. Endocrinology 112, 1490-1498.

Ricketts, A.P., Hagensee, M. \& Bullock, D.W. (1983) Characterization in primary monolayer culture of separated cell types from rabbit endometrium. $J$. Reprod. Fert. 67, 151-160.

Thatcher, W.W., Wolfenson, D., Curl, J.S., Rico, L.E., Knickerbocker, J.J., Bazer, F.W. \& Drost, M. (1984a) Prostaglandin dynamics associated with development of the bovine conceptus. Anim. Reprod. Sci. 7, 149-176.

Thatcher, W.W., Bartol, F.F., Knickerbocker, J.J., Curl, J.S. \& Wolfenson, D. (1984b) Maternal recognition of pregnancy in cattle. J. Dairy Sci. 67, 2797-2811.

Thatcher, W.W., Knickerbocker, J.J., Bartol, F.F., Bazer, F.W., Roberts, R.M. \& Drost, M. (1985) Maternal recognition of pregnancy in relation to the survival of transferred embryos: endocrine aspects. Theriogenology 23, 129-143.
Thatcher, W.W., Bazer, F.W., Sharp, D.C. \& Roberts, R.M. (1986) Interrelationships between uterus and conceptus to maintain corpus luteum function in early pregnancy: sheep, cattle, pigs and horses. $J$. Anim. Sci. 62 (Suppl. 2), 25-46.

Tolszczuk, M., Williams, L., Schimschowitch, S. \& Pelletier, G. (1985) Localisation radioautographique des récepteurs $\beta$-adrénergiques dans les trompes utérines et l'utérus chez le rat. Union Méd. Can. 114, 703, Abstr. 164.

Varma, V.A., Melin, S.A., Adamec, T.A., Dorman, B.H., Siegfried, I.S., Walton, L.A., Corney, C.N., Norton, C.R. \& Kaufman, D.G. (1982) Monolayer cultures of human endometrium: methods of culture and identification of cell types. In vitro 18, 911-918.

Verdugo, P. \& Villalon, M. (1983) Steroidal modulation of the sympathetic control of ciliary movement in the oviduct. J. Cell Biol. 97, 198A, Abstr.

Received 20 August 1987 